\title{
An Analysis of Religious Practices using Paradigm of Malayness in Burgess' Beds in the East
}

\author{
Nurhanis Sahiddan, Rosima Alias, Mardian Shah Omar, Thaharah Hilaluddin \\ College of Foundation and General Studies, Universiti Tenaga Nasional, Kajang, Malaysia \\ nurhanis@uniten.edu.my
}

\begin{abstract}
Burgess' (1917-1993) trilogy of novels, The Malayan Trilogy (1964), is probably one of the most underestimated English literary texts on the Malay World. It has been suggested that the third novel of the trilogy, Beds in the East (1959), depicts the everyday practices of the Muslim Malay characters that go against their religion, Islam, through their conversations with other Muslim Malay characters and nonMuslim characters in the novel. In this study, I utilise one of the elements under the paradigm of Malayness in literature as proposed by Ida, which is Islam. According to this concept, the paradigm of Malayness consists of everyday-defined social realities, or the six elements, the Malay language, Islam, the Malay rulers, adat/culture, ethnicity and identity. From a close textual reading of the novel, my findings show that the Malay characters in the trilogy are portrayed as wayward Muslims in their beliefs and practices. It is hoped that these findings will contribute to the on-going study on Malay Muslims, discourse and the paradigm of Malayness in literature. These findings could also be utilised by foreign students in studying the Malay culture and the Malay language.
\end{abstract}

Keywords: Conversations, Malayness, Islam, English Literature, Malay World

\section{Introduction}

This paper aims to explore how far Islam is important in constituting the paradigm of Malayness in characters that are considered as Malay in literature. This study utilises the paradigm of Malayness as an everyday-defined social reality as suggested by Ida BaizuraBahar in her unpublished thesis entitled The Paradigm of Malayness in Literature (2010). This is as opposed to Malayness as an authority-defined social reality as conceptualised by distinguished Malaysian social anthropologist Professor Datuk Dr. Shamsul or better known as Shamsul According to Ida, the paradigm of Malayness in literature consists of six elements, namely the Malay language, Islam, the Malay rulers, adat/culture, ethnicity and identity (Ida, 2010, p. 1). This is as opposed to the three pillars of Malayness which are 'agama' (Muslim religion), 'bahasa' (the Malay language) and 'raja' (the aristocrat government of the sultans) as suggested by Shamsul (2001, p. 1).

\section{Literature Review}

In an article by Ida (2012), she explores the understandings of Islam based on the proposed paradigm in her study. She has found in her study that the depictions of Islamic practices in the novel through the Malay characters show their hypocrisy and the fact that the Malays in the novel are wayward Muslims (Ida, 2012, p.5). Ida utilised two of the elements of the paradigm of Malayness in another study (2013) and found that 'Sajak-sajakSejarahMelayu' has challenged the paradigm of Malayness as an authoritydefined social reality where it is not limited only to the Malay language, Islam and the Malay rulers as an authority-defined social reality (Ida, 2013, p.174). Such results are caused by the growing roles of adat/culture, ethnicity and identity (Ida, 2013, p.174). Another example where the paradigm of Malayness has been utilised as a conceptual framework for the study of literature is a study on Malayan Muslims in Burgess' Time for a Tiger by Nurhanis Sahiddan, "Malayan Muslims as a Reflection of Malayness in Burgess' Time for a Tiger" (2013). The findings of the study show that the paradigm of Malayness in literature is not an authority-defined but an everyday-defined social reality. The study also shows and supports the view that the Malays depicted in the novel are wayward Muslims in their beliefs and practices as Malayan Muslims (Nurhanis Sahiddan, 2013, p.422).

Other than that, a paper presented by Munirah and Ida on Malayness in the translated, English version of another traditional Malay literary text Hikayat Merong Mahawangsa namely, MarongMahawangsa (The Kedah Annals), believed to have been written in the 16th Century has also implemented the paradigm of 
Malayness. In the study, Munirah and Ida utilises ethnicity and identity, which are two of the six elements of the paradigm of Malayness as explicated by Ida in her thesis (Munirah and Ida, 2013, p. 371). They use the abovementioned elements in order to examine the depictions of Islam and the Malay rulers in the translated text and their findings show that Islam, the Malay rulers and identity play a more important role in the text compared to the other elements (Munirah and Ida, 2013, p. 376).

\section{Methodology}

A close textual reading of a trilogy by Burgess (1917 - 1993) will be applied to explore how Burgess portrays the Malay characters in the trilogy in terms of their Islamic practices and whether they are wayward in their practices. Therefore, this study will analyse Burgess' understanding and views on Malayan Islam before its Independence in August 1957, as represented by the Malay characters. Based on Ida's studies, the aim of this study is to apply the six elements which constitute the paradigm of Malayness and to determine that it is in fact an everyday-defined social reality rather than an authoritydefined social reality as conceptualised by Shamsul. Another scholar, Husin states that the Malays differ from each other in terms of their Islamic belief. He also mentions that even though the Muslim Malays are Muslims in religion, some of them have deep belief in Islam and perform Islamic obligations diligently, while others do not practice the Islamic obligations accordingly such as performing the five daily prayer and fast during the month of Ramadhan (Husin, 1981, p.42). In contrast, Zawiyah's view however, states that Burgess has depicted Western generalities in the trilogy and describes them as forms of conspiratorial attack on Islam. The trilogy, as she views it, is filled with Malay characters who are religious hypocrites and sinners in Islam and shows how Burgess makes a mockery of what is highly looked upon by the Malays (Zawiyah, 2003, p.174). At the end of this paper, it will be stated whether Husin's or Zawiyah's views can be deemed as true from the text, Burgess' Beds in the East.

\section{Analysis}

In the novel being examined, Beds in the East, Syed Omar's character is again portrayed to be a wayward Muslim Malay as he drinks alcohol and goes against the obligations of Islam in marriage. In one scene, Syed Omar's fondness for drinking liquor is described where he is commenting on what he has done for his non-Malay friend, Maniam, who has been apprehended. This can be seen as follows: Syed Omar completed his morning's libation, thoughtful, surveying the rest of that lively evening. There had been no fight. There had been many restraining arms which Maniam, for his part, had not needed, for he kept saying, over and over: "I forgive him. He is still my brother. It is proper to forgive those who revile us," somewhat like an unmuscular Christian. But Syed Omar had said: "I swear in the name of God that there are clerks and peons who will bear witness that I have, myself, restrained them from doing physical harm to Maniam. But Maniam has not gone yet. There is still time. His plane does not leave till twelve tomorrow." Friends had carried Syed Omar off to a coffee-shop, and there beer and adrenaline had flowed till midnight (p. 382).

In addition, Crabbe, a non-Malay and also a non-Muslim character knows the behaviour and fondness of his friend towards liquor. Crabbe is almost encouraging Syed Omar to drink as he tells him to calm down and have another drink (p. 395). This can be seen in the conversation between Syed Omar and Crabbe:

"To him it is not good I intend to do."

"Forget it. Have another drink." (p. 395)

Even a non-Malay and non-Muslim character, Loo KamFatt, is aware of some of the most known Islamic principles and obligations. Loo KamFatt exclaims that he would no longer allow Muslim Malay girls to dance at his shop and no beer will be sold at his shop, instead he has placed a new jukebox at his shop as an attraction to his business (p. 431). Here, it can be seen that Islamic law is being upholded and understood even by the non-Malays and non-Muslims, in this case, the Chinese shopkeepers:

"Will bring trade here," shouted Loo KamFatt in his deafened happiness. "Park now closed down. No Muslim girls allowed dance now. No beer to be sold there. People here all the time. Come to hear music. Music very good thing." (p. 431)

In addition to that, Syed Omar also misuses his authority as a police by ordering beer in the presence of his son, Syed Hassan and his son's friend Hassan (p. 439). This can be seen when he argues with Loo KamFatt who refuses to sell him beer: 
... Syed Omar loudly ordered a brandy and ginger ale. Loo KamFatt said: "Cannot do. You Malay. Police say no." Syed Omar said: "I am the police. You can serve me. You must serve me. I am the police."

Syed Omar sat with the four boys and sipped his brandy and ginger ale. (p. 439)

In another occasion, drinking alcohol is again portrayed by the Malay characters. Nik Hassan pretends to order ginger ale at a gathering at the house of a non-Malay and non-Muslim character called Rosemary, whereas it is a code for brandy-ginger ale, despite the presence of his pious wife, 'CheAsma (p. 448). This can be seen in his order as follows:

"I think," said Nik Hassan, "I'd better pretend to be drinking ginger ale. She watches me like a bloody hawk, man. Here." He summoned Crabbe's boy, a shifty Chinese who loved parties, and spoke quick Malay to him. "That's all right," he said. "He knows that ginger ale is a code for brandy-ginger ale." Loudly he said: "Ginger ale, please." (p. 448).

Nik Hassan becomes frustrated that he does not get brandy-ginger ale when he orders ginger ale as a code for the alcoholic drink and becomes comedic when in reality he gets what he has asked for (p. 450). This again shows the extreme need for the Malays to drink alcohol despite such difficulties as seen below:

He grabbed Crabbe's boy - who already smelt of Beehive brandy - and handed back his glass, saying: "I asked for ginger ale. This is just ginger ale." (p. 450).

These excerpts and analyses from the trilogy indeed support Ida's view on the drinking of alcohol among the Muslim Malays. According to Ida, in Conrad's Almayer's Folly the alcoholic drinks are described as strong water in the text (Ida, 2010, p. 93). This shows the presence of the non-adherence to the Islamic teachings of avoiding alcoholic drinks and intoxicants in some English literary works on the Malay World.

In the final novel, Beds in the East, Nik Hassan, the State Information Officer with schemes in his mind, discusses with Crabbe the new position he is appointed to. Nik Hassan talks about being caught-up in between adhering to Islamic principles and climbing the social ladder which involves drinking alcohol, among others to Crabbe (p. 426). This can be seen in his conversation with Crabbe below:

Nik Hassan did not seem really pleased. "They're watching me, that's the trouble. Watching me all the time, seeing if I'm up to it. And you're never sure whether you're doing the right thing. If you drink, you're going against Islam, and if you don't drink you've got no social talents. If you've got more than one wife, they say that won't go down well in a Christian country... (p.426)

This can also be seen in Beds in the East, when a non-Malay character, Sundralingam, shares his views on Malayans who dislike other races to Maniam. Syed Omar's dislike towards other ethnic groups is made known to Sundralingam and Maniam who are Indians (p. 408). Despite Islamic teachings of prohibiting hatred toward other ethnic groups and treat others equally, Syed Omar is portrayed as a racist who likes to fight with other non-Malay characters. Sundralingm's words can be seen below:

"There is too much of all this," said Sundralingam.

“Too much despising of one's own race and too much despising of other people's races. That is going to be the big trouble of Malaya. You take this man Syed Omar. He has a mad hatred of Tamils. He imagines big Tamil conspiracies against him. Now he will nurse an even bigger hatred than before because of the thrashing he got to-day. But I personally did not want to thrash him, nor, I think, did Arumugam. You will believe me, perhaps, when I say that I felt sorry for him when he lay at the foot of the stairs. It was pathetic to see him with his poor cheap shirt on, all decorated with film stars, lying there in his blood (p.407-408)."

The evidences show how the Five Tenets of Islam is constantly broken by the Muslim Malay characters in the trilogy. This is when the Malay characters in the trilogy display negative traits in their actions and practises that in turn produces negative impressions towards the Muslim Malay characters by the nonMuslim characters in the trilogy. In her study, Ida has explicated how the actions of some Malay characters who attract negative impression by others towards them; therefore, it is assumed by nonMalays that Malays are not true believers of Islam and are hypocrites, merely using Islam as a source of power (Ida, 2010, p. 101). It could be said that the hypocrisy of the Islamic ruling as can be seen in the trilogy, does not lie with the Islamic law itself but with its implementation by its own followers (p.102). Also, my evidences point towards Husin's views where the Malays in urban areas have various chances to go against the Islamic rule. This shows the sociological aspect where the Malay community is not restricted to commit sins due to their area and location. These would also attract negative impressions 
toward the Malays who commit sin explicitly in the Malayan community. Not to forget, Zawiyah's view on the portrayal of the Malay women in the trilogy also shatters the myth of the submissive Malay woman which we can also see in Burgess' portrayal of 'CheNormah as a domineering character.

In the third novel, Beds in the East, Syed Omar discusses about the Malay youths and Muslim principles, Syed Omar comments the attire of his son's friends, Idris and Azman as well as his son, Hassan (Burgess, 2000, p. 439). Syed Omar seems proud that he is older than them and deserves to drink liquor:

"Where are the good old Muslim principles your elders tried to teach you?"

"We're not drinking brandy, anyway," said Azman boldly.

"Couldn't if you tried," said Syed Omar with contempt (p.439).

Syed Omar again ridicules the three Malay youths by saying that they are not the pride of the Malay race like him, despite being an alcoholic (p.440). This can be seen in Syed Omar's comments below:

Nobody liked to ask where or against whom they fought. They remained silent. Syed Omar said: "What will happen to Islam when it's left to milksops like you to defend it? Tell me that." (p.440)

Also, in the third and final novel, 'CheAsma, an uninterested woman, wife of Nik Hassan, is portrayed as practising rigidly Islamic teachings at a party at the house of a non-Muslim and non-Malay character, Rosemary (p. 449). 'CheAsma is portrayed as angry over a dish:

"CheAsma spat out vigorously a sliver of toast with a shive of luncheon-meat on it. "Babi!" she cried (p.449).

As 'CheAsma spits out the meat thinking that it is pork, Crabbe tries to explain that it is otherwise, but she does not believe it (p. 449). This can be seen in Crabbe's explanation:

"It isn't pork," said Crabbe. "We were very careful about that." She shrugged, unconvinced, not willing to talk to a man anyway, waiting for the Malay wives to come (p.449).

As I have shown so far, these examples support Husin's views that the Malays differ from each other in terms of their Islamic belief. The Muslim Malay characters who do not perform Islamic obligations and their belief is only skin-deep, on the contrary, would get emotionally upset if Islam is criticised, especially by non-Muslims. As S. Husin states, some Muslims believe deeply and practise Islam whereas some hardly practise it at all, same as the Malays where some seldom pray or fast according to Islam but get emotionally upset when Islam is criticised, especially by non-Muslims (Husin, 1981, p. 42). Indeed, these examples are evident in the trilogy, showing the Malay characters, although they do not practise Islam the right way in accordance to its principles, they still believe in upholding Islamic rights. Compared to Zawiyah's view however, she states that Burgess has depicted Western generalities in the trilogy and describes them as forms of conspiratorial attack on Islam. The trilogy, as she views it, is filled with Malay characters who are religious hypocrites and sinners in Islam and shows how Burgess makes a mockery of what is highly looked upon by the Malays (Zawiyah, 2003, p. 174). Although it is true that Burgess portrays the Malay characters in the trilogy as wayward Muslims, his portrayal of the characters are not believed to be a conspiratorial attack or mockery towards Islam, but showing that the practice of Islam has been depicted within the sociological perspective of the Malays in the trilogy as an everyday-defined social reality, and not shaped by colonial knowledge. The Malay characters portrayed by Burgess are no doubt perceive themselves Malays and this fact is made known clearly to other Malay and non-Malay characters in the trilogy.

\section{Conclusion}

All in all, the analysis of the novel Beds in the East shows that Burgess has portrayed the Muslim Malay characters as wayward in their Islamic beliefs and practices. Also in accordance to Ida's conceptualisation of Islam as an element of the paradigm of Malayness in literature, it can be derived from the analysis of Burgess' Muslim Malay characters that they practise wayward Islamic beliefs and practices. The primary framework based on Ida's study, have been useful in analysing Burgess' Muslim Malay characters. Islam can be said to be a predominant element in Burgess' novel and the element of Islam from Ida's study has been fully utilised for the analysis of Burgess' novel. Therefore, my analysis on the novel Beds in the East supports Ida's views where the paradigm of Malayness in literature is in fact, an everyday-defined social reality, shaped by their everyday practices and beliefs, and is not shaped by colonial knowledge, or is authoritatively-defined. My analysis also shows that, based on the sociological perspective of Husin, communal practices of the Muslim Malays in Burgess' trilogy prove that the Muslim Malay practices are 
an everyday-defined social reality. However, Zawiyah's view that Burgess' makes a mockery of Islam in the trilogy has found to be unsupported as can be seen in my analysis.

Recommendations: As a suggestion for future studies, this study will enrich future research on Burgess' The Malayan Trilogy which I believe has been greatly overlooked. It is believed that the trilogy has many potential for research pertaining to English literature on the Malay World. Other than that, the trilogy is a very suitable text for a researcher to examine the portrayals of the Malay characters as well as the Malay World from the sociological perspective. Other future research could also use Burgess' texts by applying other literary approaches and theoretical frameworks, such as postcolonial theory and new historicism theory, among others. Research on the paradigm of Malayness in literature should be studied further to cover various genres of literature on the Malay World, such as short stories and poems. In addition, this study would provide a basis for some studies on not only on English literature on the Malay World and Malayness, but also to the study on non-Muslim perspective towards Islam in literature. These areas of studies mentioned are scarce in resource; therefore, I hope my study and other future studies on these subject matters will contribute to the knowledge pool on other related filed of studies.

Finally, I hope that my study on the paradigm of Malayness in literature can be utilised as a framework using other texts by contemporary writers in English literature who have written works set in the Malay World, such as Map of the Invisible World (2009) by Tash Aw (b. 1971) and Horror Stories(2013)by Tunku Halim (b. 1964). These findings may contribute to the on-going study on Malay Muslims, discourse and the paradigm of Malayness in literature. These findings could also be utilised by foreign students in studying the Malay culture and the Malay language. This is because courses on Malay culture, Malaysian studies and Malay language have been made compulsory to many universities, one for instance is in University Tenaga Malaysia (UNITEN).

\section{References}

Burgess, A. (2000). The Malayan Trilogy. London: Vintage.

Ida, B. (2010). The Paradigm of Malayness in Literature. (Unpublished doctoral dissertation). SOAS University of London, UK.

Ida, B. (2012). Sustaining Diversities through Understandings of Islam within Malayness: Reflections in Anthony Burgess' The Malayan Trilogy. Proceedings of the $7^{\text {th }}$ Malaysia International Conference on Languages, Literatures, and Cultures. Malaysia: Universiti Putra Malaysia.

Ida, B. (2013). Islam and the Malay Rulers as the Paradigm of Malayness in Sajak-sajakSejarahMelayu. Paper presented at The International Seminar on Malay Studies 2013, Universiti Malaya, Kuala Lumpur.

Munirah, M. A. \& Ida, B. (2013). An Exploration of Malayness in MarongMahawangsa (The Kedah Annals).Paper presented at The International Seminar on Malay Studies 2013, Universiti Malaya, Kuala Lumpur.

Nurhanis, S. (2013). Malayan Muslims as a reflection of Malayness in Anthony Burgess's Time for a Tiger. Paper presented at The International Seminar on Malay Studies 2013, Universiti Malaya, Kuala Lumpur.

Husin S. A. (1981). The Malays Their Problems and Future. Petaling Jaya: Heinemann Asia, 1981. Print.

Shamsul, A. B. (2001). A History of an Identity, an Identity of a History: The Idea and Practice of 'Malayness' in Malaysia Reconsidered. Journal of Southeast Asian Studies, 32(3), 355-366.

Zawiah, Y. (2003). Resisting Colonialist Discourse. (2nded). Bangi: Penerbit Universiti Kebangsaan Malaysia. 